\title{
Antibacterial and cytotoxic activity of Kenyan medicinal plants
}

\author{
Wagate G Cyrus/ ${ }^{+}$, Gakuya W Daniel' ${ }^{1}$, Mark O Nanyingi, Francis K Njonge ${ }^{2}$, James M Mbaria
}

Department of Public Health, Pharmacology and Toxicology 'Department of Clinical Studies, Faculty of Veterinary Medicine, University of Nairobi, PO Box 29053, 00625 Nairobi, Kenya ${ }^{2}$ Department of Chemistry, Jomo Kenyatta University of Agriculture and Technology,

Nairobi, Kenya

Seven medicinal plant extracts traditionally used in Kenya, mainly for management of infectious conditions, were chosen and screened for their antibacterial activity against Gram-negative (Pseudomonas aeruginosa and Escherichia coli) and Gram-positive (Bacillus cereus and Staphylococcus aureus) bacteria. Antibacterial activity was tested using the broth dilution method. Harrisonia abyssinica and Terminalia kilimandscharica extracts showed significant activity against Gram + and Gram- bacteria. The methanolic extracts of $\mathrm{T}$. kilimandscharica bark and $\mathrm{H}$. abyssinica bark and leaves showed minimum inhibitory activity against all tested bacteria, with minimal inhibitory concentrations ranging from 25-150 mg/mL. Ajuga remota and Amaranthus hybridus, which are lethal to brine shrimp nauplii, showed significantly lower antibacterial activity than those that were relatively non-toxic.

Key words: antibacterial - cytotoxicity - medicinal plants

Traditional medicine is widely practiced in Kenya, where this has been documented by ethnobotanical surveys (Miaron et al. 2004, Kareru et al. 2007, Njoroge \& Bussman 2007). The high cost of imported conventional drugs and/or inaccessibility to western health care facilities has led to overreliance on traditional medicine since it is affordable and available to rural people. On the other hand, even when western health facilities are available, traditional medicine is viewed as an efficient and an acceptable system from a cultural perspective (Munguti 1997, Miaron et al. 2004).

Infections associated with bacterial pathogens are among some of the indications treated using traditional remedies in Kenya (Njoroge \& Bussman 2007). Bacterial infections are prevalent due to various factors such as the HIV/AIDS pandemic, poor hygiene, overcrowding and resistance to convectional antimicrobials. Natural products of higher plants may provide a new source of antimicrobial agents with possibly novel mechanisms of action (Adenisa et al. 2000).

The aim of this study was to screen methanolic medicinal plant extracts traditionally used for the management of infectious diseases in Kenya. Brine shrimp (Artemia salina Leach) lethality test (BSLA) was used to systematically evaluate the cytotoxic effects of extracts. Broth dilution assays using Gram-negative bacteria Escherichia coli (ATCC 25922) and Pseudomonas aerugenosa (ATCC 27853) and Gram-positive bacteria Staphylococcus aureus (ATCC25923) and Bacillus cereus (ATCC 11778) was utilized to obtain the minimal inhibitory concentrations (MIC) of the plant extracts.

Financial support: Commission of Higher Education (CHE/1/26/1/4, PI: JM Mbaria)

+ Corresponding author: gwagate@yahoo.com

Received 3 April 2008

Accepted 16 September 2008

\section{MATERIALS AND METHODS}

Plant materials - Plants were collected during dry season from January-March 2006 in Machakos and Kitui areas of the Eastern province, Kenya, based on ethnopharmacological use through interviews with traditional health practitioners. The plants were identified by Mr. Ochung, a plant taxonomist, and voucher specimens (Table I) were deposited at the Department of Land Resource Management and Agricultural Technology Herbarium, University of Nairobi.

Extraction - The plant parts (whole plant, bark, root, leaves, tubers or a mixture) were chopped into small pieces, air dried at $\mathrm{rt}\left(25^{\circ} \mathrm{C}\right)$ under shade and pulverized using a laboratory mill yielding $300-400 \mathrm{~g}$. The fine powders were separately soaked in $70 \%$ methanol $(3 \times$ $500 \mathrm{~mL}$ ) for four days at rt to produce extracts. The extracts were filtered and concentrated using rota vapor at $50^{\circ} \mathrm{C}$ and 100 mbar. Further preparation was done according to Gebre-Mariam et al. (2006). The lyophilized extracts were kept at $+4^{\circ} \mathrm{C}$ until they were screened. The yields of the methanol extracts were between 5\%$8.4 \%$. The methanolic extract yields were obtained as follows: leaves of Ajuga remota Benth (320 g) yielded $7.5 \%$, leaves of Amaranthus hybridus L. (350 g) yielded $4.2 \%$, leaves of Cassia didymobotrya Fres. (320 g) yielded 8.4\%, a mixture of leaves and roots of Croton macrostachyus Del. (400 g) yielded 5.2\%, tubers of Entada leptostachya Harms (300 g) yielded 6\%, mixture of leaves and bark of Harrisonia abyssinica Oliv (360 g) yielded $6.5 \%$ and bark of Terminalia kilimandscharica Engl. $(370 \mathrm{~g})$ yielded $7.2 \%$.

Antibacterial assay - Preliminary antimicrobial testing was done using the disk diffusion (Kirby-Bauer) method (Kirby et al. 1966). The disks were put in a clean glass bottle and sterilized at $121^{\circ} \mathrm{C}$ for $15 \mathrm{~min}$ in an autoclave. Broth dilution assay was used to screen the extracts for antibacterial activity. The bacterial strains were obtained from the Department of Public Health, Pharmacology and Toxicology, University of Nairobi. 
TABLE I

Botanical identification, their uses, and parts used of medicinal plants studied

\begin{tabular}{|c|c|c|c|c|c|}
\hline Species & Parts & Voucher n & Family & Vernacular name & Therapeutic indications \\
\hline Ajuga remota Benth & $\mathrm{L}$ & CW5 & Lamiaceae & Katetema & Malaria, boils \\
\hline Amaranthus hybridus L. & $\mathrm{Wp}$ & CW10 & Caesalpinaceae & Muvisi/musavula & $\begin{array}{l}\text { Urinay tract infection, } \\
\text { kidney and stomach ailments }\end{array}$ \\
\hline Cassia didymobotrya Fres. & $\mathrm{L}$ & CW9 & Caesalpinaceae & Muthaa & Typhoid \\
\hline Croton macrostachyus Del. & $\mathrm{L}, \mathrm{R}$ & CW6 & Euphorbiaceae & Mukambi/kitundu & Typhoid, measles \\
\hline Entada leptostachya Harms & $\mathrm{T}$ & CW4 & Mimosaceae & Mwaitha & Tuberculosis, cough \\
\hline Harrisonia abyssinica Oliv & $\mathrm{L}, \mathrm{B}$ & CW1 & Simaroubaceae & Muthiia & $\begin{array}{l}\text { Pneumonia, syphilis, infertility, } \\
\text { malaria, stomach, eye ointment }\end{array}$ \\
\hline Terminalia kilimandscharica Engl. & . $\mathrm{B}$ & CW3 & Combretaceae & Muuku & $\begin{array}{l}\text { Cough, sexually transmitted } \\
\text { diseases }\end{array}$ \\
\hline
\end{tabular}

B: bark; L: leaves; R: roots; T: tuber; Wp: whole plant.

The bacterial inoculums of each reference bacteria were obtained from fresh colonies in Mueller Hinton agar $\left(\right.$ Oxoid $\left.^{\circledR} \mathrm{UK}\right)$ plates. Suspension of approximately $2.2 \times$ $10^{8} \mathrm{cfu} / \mathrm{mL}$ in sterile normal saline was prepared according to Shahidi (2004). Stock solutions of plant extracts of $200 \mathrm{mg} / \mathrm{mL}$ were made separately for each plant species and, from this, two-fold serial dilutions were prepared in sterile Mueller Hinton Broth (Oxoid $\AA$, UK). A tenth of a milliliter of bacterial suspension was dispensed into each test tube. Pure solvents were used as negative controls. The tubes were incubated at $37^{\circ} \mathrm{C}$ for $24 \mathrm{~h}$. The MIC was defined as the lowest concentration that inhibited any visible bacterial growth on the culture plates (Shahidi 2004). Benzyl penicillin and streptomycin antibiotics (Apothekernes Laboratorium, Oslo) were used as standard control drugs.

$B S L A$ - Lethality testing was done according to McLaughlin (1991). Three dilutions of extract were prepared by transferring $500 \mu \mathrm{L}, 50 \mu \mathrm{L}$ and $5 \mu \mathrm{L}$ to the set of five graduated tubes. Ten shrimp nauplii were transferred into each of the vial using Pasteur pipette. Marine salt was added to the $5 \mathrm{~mL}$ mark to produce a final concentration of $1000 \mu \mathrm{g} / \mathrm{mL}, 100 \mu \mathrm{g} / \mathrm{mL}$ and $10 \mu \mathrm{g} /$ $\mathrm{mL}$. After $24 \mathrm{~h}$ exposure, the live nauplii were counted and the $\mathrm{LC}_{50}$ calculated using the probit analysis (Finney 1971). Standard controls with and without Vincristin (Oncovin $\AA$ ) were run simultaneously.

Ethics - Prior consent of respondents was obtained with adherence to National Regulatory guidelines on intellectual property rights. The field work surveys and quantitative data collection were conducted in accordance with the institutional, national and international principles and guidelines of plant use and conservation of biodiversity.

\section{RESULTS AND DISCUSSION}

Results are shown in Tables 1-3. The antibacterial activity was considered significant if the MIC $\leq 200 \mathrm{mg}$ / $\mathrm{mL}$ (Suffredini et al. 2006). The extracts of T. kilimandscharica and $H$. abyssinica produced significant activity against all test bacteria. $B$. cereus was inhibited at an MIC of $\leq 150 \mathrm{mg} / \mathrm{mL}$ by all the plant extracts screened in the current study. From the seven species studied, $28 \%$ showed inhibitory activity against Ps. aeruginosa at $\leq 75 \mathrm{mg} / \mathrm{mL}$. The extract of bark and mixture of bark and leaves were the most active against the test bacteria. The tuber extract of E. leptostachya was the least active; $P$ s. aeruginosa showed resistance while $B$. cereus was the most sensitive to plant extracts.

Brine shrimp is a low cost bench bioassay indicative of cytotoxic, pesticidal, heavy metal toxicity, insecticidal and antifeedant properties. There was no correlation between BSLA and bacteriostatic properties that could be deduced in this study. Nonetheless, the plant extracts that were lethal to brine shrimp nauplii also had low inhibitory activity against bacteria. From the plant extracts, only $A$. remota had an $\mathrm{LC}_{50}$ of $<100 \mu \mathrm{g} / \mathrm{mL}$, which was considered toxic. The other plant species had an $\mathrm{LC}_{50}$ of $<1000 \mu \mathrm{g} / \mathrm{mL}$, which was considered relatively non-toxic (Santos et al. 2003).

Some of the genera investigated in the present study have been known to contain pharmacologically active compounds. Combrestatins and flavonoids have been isolated from Terminalia sp. (Garcez et al. 2006), terpenoids, glycosides, ajugarin I and II have been isolated from the Lamiaceae family (Matu \& van Staden 2003, Manguro et al. 2006), antioxidants and phenols from $A$. remota (Chitindingu et al. 2007), an antifungal thaumatin-like protein from Cassia didymobotrya (Vitali et al. 2006) and saponins isolated from E. leptostachya (Ka-reru et al. 2008).

The present study supports the continued sustainable use of medicinal plant resources backed by scientific validation. Phytochemical elucidation of antibacterial and cytotoxic principles of $H$. abyssinica, A. remota, A. hybridus, T. kilimandscharica and $C$. didymobotrya should be undertaken with the objective to isolate the active biochemical principles and develop novel antimicrobial agents.

\section{ACKNOWLEDGEMENTS}

To members of Ukamba Herbalist Society, for their cooperation during the field data collection, and to Mr. Ochung, Herbarium Curator, LARMAT, University of Nairobi, for botanical identification of the plants.

\section{REFERENCES}

Adenisa SK, Idowu O, Ogundaini AO, Oladimeji H, Olugbade TA, Onawunmi GO, Pais M 2000. Antimicrobial constituents of the leaves of Acalypha wilkesiana and Acalypha hispida. Phytother Res 14: 371-374. 
TABLE II

Minimum inhibitory concentration obtained for methanolic extracts

\begin{tabular}{|c|c|c|c|c|}
\hline \multirow[b]{2}{*}{ Plant species } & \multicolumn{4}{|c|}{ Bacterial strains $(\mathrm{mg} / \mathrm{mL})$} \\
\hline & S. aureus & B. cereus & P. aerugenosa & E. coli \\
\hline Ajuga remota Benth & 7.8 & 15.6 & - & 31.25 \\
\hline Amaranthus hybridus L. & 7.8 & 15.6 & - & 31.25 \\
\hline Cassia didymobotrya $\mathrm{Fes}$ & 15.6 & 15.6 & - & 62.5 \\
\hline Croton macrostachyus Del. & - & 15.6 & 250 & 250 \\
\hline Entada leptostachya Harms & - & 125 & 250 & - \\
\hline Harrisonia abyssinica Oliv & 25 & 15.6 & 37.5 & 150 \\
\hline Terminalia kilimandscharica Engl. & 100 & 15.6 & 75 & 150 \\
\hline Streptomycin ${ }^{\mathrm{a}}$ & & & 0.25 & 0.25 \\
\hline Benzylpenicillin $^{\mathrm{a}}$ & 0.6 & 0.6 & & \\
\hline
\end{tabular}

$a$ : antibiotics.

TABLE III

Brine shrimp test of methanol extracts. The results are presented as lethal concentration $50\left(\mathrm{LC}_{50}\right)$ values $(\mu \mathrm{g} / \mathrm{mL})$ and $95 \%$ confidence

\begin{tabular}{lccc}
\hline Botanical name & Parts & $\mathrm{LC}_{50}(\mu \mathrm{g} / \mathrm{mL})$ & $95 \% \mathrm{CI}$ \\
\hline Ajuga remota Benth. & $\mathrm{L}$ & 61.6 & $19.8-144.6$ \\
Amaranthus hybridus L. & $\mathrm{Wp}$ & 116.1 & $45.1-316.7$ \\
Cassia didymobotrya Fres. & $\mathrm{L}$ & 230.9 & $91.3-650.9$ \\
Croton macrostachyus Del. & $\mathrm{L}, \mathrm{R}$ & 387.1 & $160.2-936.9$ \\
Entada leptostachya Harms. & $\mathrm{T}$ & 421.3 & $127.9-6301.3$ \\
Harrisonia abyssinica Oliv. & $\mathrm{L}, \mathrm{B}$ & 392.4 & $103.1-15928.6$ \\
Terminalia kilimandscharica Engl. & $\mathrm{B}$ & 164.1 & $56.6-502.8$ \\
Vincristri (Oncovin $(\mathbb{R})$ & & $<1$ &
\end{tabular}

B: bark; CI: intervals; L: leaves; R: roots; T: tuber; Wp: whole plant.

Chitindingu K, Ndhlala AR, Chapano C, Benhura MA, Muchuweti M 2007. Phenolic compound content, profiles and antioxidant activities of Amaranthus hybridus (pigweed), Brachiaria brizantha (upright brachiaria) and Panicum maximum (guinea grass). $J$ Food Biochem 31: 206-216.

Finney DJ 1971. Probit analysis, 3rd ed., Cambridge University Press, Cambridge, 333 pp.

Garcez FR, Garcez WS, Santana AD, Alves MM, Matos MC, Scaliantea AM 2006. Bioactive flavonoids and triterpenes from Terminalia fagifolia (Combretaceae). J Br Chem Soc 17: 1223-1228.

Gebre-Mariam T, Neubert R, Schmidt PC, Wutzler P, Schmidtke M 2006. Antiviral activities of some Ethiopian medicinal plants used for the treatment of dermatological disorders. J Ethnopharmacol 104: 182-187.

Kareru G, Kenji M, Gachanja N, Keriko M, Mungai G 2007. Traditional medicines among the Embu and Mbeere peoples of Kenya. Afr J Trad CAM 4: 75-86.

Kareru G, Keriko M, Gachanja N, Kenji M 2008. Direct detection of triterpenoid saponins in medicinal plants. Afr J Trad CAM 5: $56-60$

Kirby M, Bauer A, Sherris C, Turck M 1966. Antibiotic susceptibility testing by a standardized single disk method. Amer J Clin Pathol 45: 493-496.

Manguro-Arot LO, Wagai OS, Lemmen P 2006. Flavonol and iridoid glycosides of Ajuga remota aerial parts. Phytochemistry 67: 830-837.

Matu EN, van Staden J 2003. Antibacterial and anti-inflammatory activities of some plants used for medicinal purposes in Kenya. $J$ Ethnopharmacol 87: 35-41.

McLaughlin JL, Chang CJ, Smith DL 1991. Bench-top bioassays for the discovery of bioactive natural products: an update. In A Rahman (ed.), Studies in Natural Product Chemistry 9, Elsevier, Amsterdam, pp. 383-409.

Miaron OJ, Kassim O, Ekaya N 2004. Indigenous knowledge: the basis of the Maasai Ethnoveterinary Diagnostic Skills. J Hum Ecol 16: 43-48.

Munguti K 1997. Indigenous knowledge in the management of malaria and visceral leishmaniasis among the Tugen of Kenya. Indig Knowl Dev Monitor 5: 10-12.

Njoroge GN, Bussmann RW 2007. Ethnotherapeautic management of skin diseases among the Kikuyus of Central Kenya. J Ethnopharmacol 111: 303-307.

Santos LP, Pinto GB, Takahashi JA, Silva LG, Boaventura MA 2003. Biological screening of Annonaceous Brazilian medicinal plants using Artemia salina (Brine Shrimp Test). Phytomedicine 10: 209-212.

Shahidi BH 2004. Evaluation of antimicrobial properties of Iranian medicinal plants against Micrococcus luteus, Serratia marcescens, Klebsiella pneumoniae and Bordetella bronchoseptica. Asian J Plant Sci 3: 82-86.

Suffredini IB, Paciencia MLB, Nepomuceno DC, Younes RN, Varella AD 2006. Antibacterial and cytotoxic activity of Brazilian plant extracts Clusiaceae. Mem Inst Oswaldo Cruz 101: 287-290.

Vitali A, Pacini E, De Mori P, Pucillo L, Maras B, Botta B, Brancaccio A, Giardina B 2006. Purification and characterization of an antifungal thaumatin-like protein from Cassia didymobotrya cell culture. Plant Physiol Biochem 44: 604-610. 